\title{
Effects of Tax Audit on Revenue Collection Performance in Ethiopia Evidence from ERCA Large Taxpayers' Branch Office
}

\author{
Goshu Desalegn (Msc) \\ Lecturer@ the Department of Accounting and Finance, Addis Ababa, Ethiopia
}

\begin{abstract}
This study examines the effect of tax audit on revenue collection performance evidenced from ERCA-LTO. The objective of the study is to examine the effect of tax audit on revenue collection performance. In doing so, tax audit is measured by nine variables (tax audit resources, audit case selection, capacity of auditors, tax protection system, tax automation, and tax evasion, and tax compliance, amount before and after audit). The study uses explanatory research design and mixed research approach with secondary data utilized over the study period 20052011 E.C (7 years). The data is collected both from primary and secondary source of data. More specifically, the study adopts a multiple regression model. The finding of the study reveals that; tax compliance, revenue protection system, and tax automation has positive and significant effect on revenue collection and statically significant at $1 \%, 1 \%$ and $5 \%$ significant level respectively. Furthermore, audit case selection and auditors capacity has a positive and significant effect on revenue collection performance at 10 percent significance level. Apart from this, the variable tax audit resource, tax evasion and before audit amount has a negative effect on revenue collection and statically significant at 1 percent significance level. On the other hand the amount after audit has positive and insignificant effect on revenue collection performance.
\end{abstract}

Keywords: Tax audit, Revenue collection, multiple regression analysis

DOI: $10.7176 / \mathrm{RJFA} / 11-7-01$

Publication date: April $30^{\text {th }} 2020$

\section{Introduction}

The development of any nation depends on the amount of revenue generated and applied by the government on public infrastructure for the benefits of members of that society. No economy can grow without adequate resources for infrastructural development and provision of power and public utilities and services. Taxes and tax systems are fundamental components of any attempts to build nations, and this is particularly the case in developing or transitional nations (McKerchar and Evans, 2009). In addition to this, since the primary objective of taxation is to raising the governments' revenue to finance its expenditure for all economic activities. There is growing international interest in improving the ability to develop countries to mobilize domestic revenue from different resources (Damme et al., 2008). Domestic resource mobilization (DRM) refers to the process in which countries raise domestic resources and spend these funds to provide goods and services to their people. This includes tax collection, non- tax revenues, domestic borrowing, and other domestic income sources but it doesn't necessarily have to mean introducing new taxes or increasing the tax rates. For developing countries, DRM is the only dependable and long-term source of development financing in terms of sustainability and reliability (Azubike, 2009). However, developing countries have had difficulties in mobilizing resources for investment from domestic sources.

It has been evidenced that expenditure programs in developing countries have been hampered by low tax revenues (Tanzi et al., 2000). With this regard, a number of scholars were agreed on the importance of a good tax system to achieve government objectives. For example, according to Azubike (2009) and Okezie (2003), a good tax system (which includes tax audit) is an opportunity for the government to collect additional revenue needed in discharging its present obligations and plays multiple roles in the process of economic development of any nation. A tax audit is an examination of whether a taxpayer has correctly reported its tax liability and fulfilled other obligations. It is often more detailed and extensive than other types of examinations such as general desk checks, compliance visits or document matching programs (OECD, 2006a). In addition to this, tax audits are an examination of taxpayer's business records and financial affairs to ensure taxpayers have computed their tax payable in accordance with the current tax laws and regulations (Isa et al. 2011). Furthermore, according to Al Zakari (1995), tax audit is an examination of the historical financial statements and other documentary evidences for the preparation of current tax returns, as well as the supporting working statements, followed by an audit report giving the auditors' opinion about the degree of correspondence between the information contained in the tax return and the regulatory provisions of tax laws. So, tax audit affects revenue collection in that it promotes voluntary compliance of taxpayers which increases revenue and determines the accuracy of returns so as to ensure the right taxes are submitted. Furthermore, tax liability can be easily declared and matters that need adjustment are easily identified. It also helps in collecting tax interests and penalties which thereby increase revenue collection 
(Bello, 2001). Specifically, to discuss this issue in the context of Ethiopia (the effect of tax audit on revenue collection), in the past decade Ethiopia has made encouraging progress in mobilizing more revenues from domestic sources, particularly in tax revenue. Tax collection increased from Birr12.4 billion in 2005 to Birr 165.3 billion in 2015 indicating over a thirteen-fold increase in the decade (UNDP, 2016). Similarly, the share of domestic revenue in the total public revenue increased from 77 percent to 94 percent in the same period, and the share of tax revenue stands at 83 percent in 2015 . However, there is a challenge increasing the tax revenue proportionate GDP; the tax to GDP ratio remained low at 7.6 percent in 2018 which is below the Sub Saharan Average of about 18percent, over 20 percent for emerging economies and above 30percent for developed economies (IMF Report, 2018). According to the IMF report (2018), in 2005, Ethiopians' tax to GDP ratio was 13 percent, but this ratio is dramatically declines to 7.6 percent in 2017 . While the economy has been growing at a remarkable rate averaging more than 10 percent, the slow growth in the tax to GDP ratio suggests the growth in tax collection is not commensurate with the economic growth perhaps indicating a huge untaxed potential (UNDP, 2016).

According to Shumetie (2019), there are a number of reasons in Ethiopia which leads to revenue collection in danger position because of the improper tax audit. The reasons were highlighted by Shumetie (2019) for improper tax audit was; case selection is not based on the availability of resource for tax audit, taxpayers were not co-operated to give their source documents, do not respect the tax law, lack of good awareness on tax, not happy while they are noticed to be audited and taxpayers are mostly unwilling to release vital records. With this regard, the Government of Ethiopia continued to carry out tax reforms over the years with an aim of improving tax efficiency and increasing the amount of revenue raised to finance the government expenditure but tax revenue to GDP ratio is still less than the average ratio of sub-Saharan countries (UNDP, 2016). Following this, one may ask, why this low tax to GDP ratio for Ethiopia? Is it due to the structure of the economy? Is it due to the inefficiency of the tax administration in tackling exhaustively all tax revenue potential or what? Therefore; this study seeks to answers what are essentially the effects of tax audit on revenue collection in Ethiopian Revenue and Customs Authority large taxpayers' branch office? So, the main objective of this study is to examine the effects of tax audits on revenue collection in ERCA by taking a case study of large taxpayers' branch offices.

\section{Specific objectives of the study}

1 To examine the effect of tax audit resources, auditors capacity, audit case selection, revenue protection system, tax automation on revenue collection performance in ERCA-LTO.

2 To examine the effect of before audit income of tax payers, after audit income of tax payers, tax compliance, tax evasion on revenue collection performance in ERCA.

\section{LITERATURE}

Tax audit is an examination of a taxpayer's financial report by tax collector bodies to ascertain compliance with the tax legislation of a country (Kircher, 2008). Additionally, tax audit is a process where the tax authority to confirm the amount of tax payable that the taxpayer declared correctly or not. Accordingly, OECD (2006), a tax audit is an investigation of the correctness of liabilities and fulfilling of tax obligations reported by taxpayers. On the other hand, Adediran et al. (2013) addressed that, the tax audit just like financial audit involves the gathering of information and processing it for determining the level of compliance of an organization with tax laws of the country. For a successful audit, it is necessary that the assignment is accomplished, completely and efficiently. Regarding empirical pieces of evidence on Tax Audit and revenue collection, the researcher comes across different studies carried out at specifying organizations in different countries but scanty studies that have been conducted to establish the potential effect of tax audit on revenue collection. The following subsection incorporates a number of studies conducted around tax audit and revenue collection.

Among the study conducted at a global level, Bright et al. (1988) studied statistical sampling for tax audits in the United States of America. The study tried to review whether the use of statistical sampling for audit is a sufficient basis for determining the taxpayer's unpaid liability rather than reviewing all transactions to determine the exact amount of tax owed. The study relied on the cases and data from consumption taxes, primarily sales and use taxes. The universe-documented transactions available for audit are used as a sample frame. The finding of the study indicated that audit assessment based on appropriately drawn and analyzed statistical sample do not suffer from the defects that the courts have correctly concluded assessments based on non-statistical samples. The study further indicated that sampling techniques allow improved economies in the use of government resources in that tax administration can be more efficient, fairer, and less intrusive if the technologies used for identifying and measuring tax deficiencies are expanded to include controlled use of statistical sampling. However, statistical sampling cannot provide an exact determination of tax owed, and the uncertainty adjustment may sacrifice too much revenue.

Yet another study was conducted by Smith and Stalans (1994) in the USA, on negotiating strategies preferred by taxpayers and auditors for dealing with tax audit disputes. The study adopted a pre-audit open-ended interview conducted with a randomly selected sample of taxpayers and state tax auditors that have drawn from four field 
offices of the Oregon Department of Revenue. The results of this study revealed that the strategic preferences of both taxpayers and auditors are influenced by the nature of the dispute, general taxpayers' attitudes toward taxpaying and tax administration, the difference informal power, and the perceived role obligations of auditors. As the study results showed, tax auditors are more likely to include holding firm as one of their strategic choices. Whereas taxpayers who have an objective to minimize the time and effort they devote to the audit are more likely to prefer the cooperative strategies, but those taxpayers who believe that they can influence the decision making of the auditor are more likely to prefer the assertive strategies. The study further indicated that taxpayers who support taking advantage of loopholes and ambiguities in the tax law tend to prefer the assertive strategies, and those who want to minimize their involvement are more likely to prefer cooperative strategies. Furthermore, there was another study conducted in the USA by Rhoades (1999) on the impact of multiple components reporting on tax compliance and audit strategies. The study modeled taxpayer compliance behavior and tax authority audit strategies within the context of a multidimensional report of taxable income and analyzed the impact of component reporting requirements on taxpayer incentives to misstate the tax liability. The results of the study revealed that the impact of multicomponent reporting requirements on specific taxpayers depends critically on their evasion opportunity set. The study stated that taxpayers with multiple evasion opportunities made misstatement across income components to minimize both the direct and indirect effects of detection whereas those with limited evasion opportunities pursued them less aggressively in the multicomponent model. Besides, Chan and Mo (2000) studied the effect of tax-holidays on foreign investors' tax noncompliance behavior in China's developing economy. The empirical results of the study indicated that a company's tax-holiday position affects noncompliance. Companies are least compliant during the pre-holiday period whereas most compliant during the tax exemption period. The study further indicated that domestic market-oriented companies, service companies, and joint ventures are less compliant than export-oriented companies, manufacturing companies, and wholly foreign-owned enterprises respectively. Likewise, Sen and Bala (2002) studied income tax audit operations in Bangladesh. The objective of the study was to conceptualize the term tax audit conducted by professional chartered accountants and to give an overview of the prevailing tax scenario and the operations of the income tax audit. The results of the study confirmed that Bangladesh is unable to raise enough resources through taxes. The study also revealed that income tax audit is conducted both in a mandatory and discretionary manner although the extent of income tax audit practice is awfully inadequate. The major reasons identified in the study were unawareness and undesirability of most assess, and the hesitation of chartered accountant firms to take up the task of tax audit. The hesitation of chartered accountant firms is because the sensitivity of the tax audit task spreads not only in the relevant year but also in the future years until the finalization of the audit. Moreover, they often reluctant to perform the audit of tax basis accounting due to inadequacy of information, lack of efficient personnel, absence of audit continuity over the years, and want of logistic supports to maintain the track record of information for future reference in tax cases. Furthermore, Arachi and Santoro (2007) also studied the use of tax audit strategy as enforcement for small and medium enterprises in Italy. The study focused on a major innovation in the field of tax auditing of self-employed workers and small firms. The main finding of the study was that tax enforcement for SMEs is always challenging since they usually operate on the border between the formal and the shadow economy. The study further showed that the distribution of firm size affects the optimal tax enforcement policy in two ways. First, there can be a relationship between firm size and the propensity to evade or to avoid taxes. Second, the costs and returns of tax auditing may depend on firm size. The study also argued that business sector analysis might be a valuable policy tool for developing countries, which have a large shadow economy and a high share of microenterprises. Moreover, the findings of a study conducted on Taxation and Tax Audit Challenges across 58 developing countries (Carnahan, 2015), revenue systems in some developing countries have fundamental shortcomings. Besides, the increasing globalization of economic activity adds a further layer of complexity that developing countries need to manage in building and maintaining their revenue systems. Similarly, a study conducted in the Gombe state of Nigeria by Gurama (2015), with the main objective to examine the problems and prospect of Tax Audit and internal revenue services; also identified tax audit problems related to poor staffing, lack of facilities, poor record-keeping, and poor conducive environment. The findings show that insufficient public awareness, lack of training, poor working condition, poor remuneration and lack of motivational incentives are among the issues lead to low tax generation.

Mirera (2014) conducted study on the effects of tax audit on revenue collection in the case of the Kenya Revenue Authority. The study was limited to the Nairobi West region of the Kenya Revenue Authority and adopted a descriptive research approach. The study was conducted through secondary source of data. The Data was analyzed using T-test analytical model. The finding of the study shows that the t-statistics results the parametric Pearson correlation or , $\mathrm{r}^{\text {ee }}$ value was significant for tax paid before audit and tax paid after audit which clearly indicates there is an increase in the tax paid after the audit. Thus, it is right to say that tax audit is directly related to revenue collection. The study recommends that the tax audit reports be submitted to the public and a standard procedure to be found in choosing the companies that random audit is conducted. Additionally, Harelimana (2018) conducted a study on the effects of tax audits on revenue collection in Rwanda. The study was limited to the 110 respondents of Headquarter of the Rwanda Revenue Authority (RRA) in Kigali. The study adopted a descriptive 
approach. Both Primary and secondary data were used and then analyzed through SPSS version 21. Data analysis involved statistical computations for averages, percentages, and correlation and regression analysis. Ordinary least squares (OLS) regression method of analysis was adopted to determine the inferential statistics. From the findings of the study, tax administration, tax revenue performance, revenue protection system, tax automation to a constant zero, revenue collection was at 0.347. A unit increase on Tax administration was lead to increase in revenue collection by a factor of 0.162 , a unit increase in tax revenue performance was lead to increase in revenue collection by a factor of 0.282 , a unit increase in revenue protection system was lead to increase in revenue collection by a factor of 0.194 and unit increase in tax automation was lead to increase in revenue collection by a factor of 0.211 . Therefore, the finding of the study suggests that tax audit has an effect on revenue collection as according to the t-tests there was significance in the correlation between tax collected before the audit and after the audit. Additionally, Gebeyehu (2008) was attempted to trace out the basic concepts of tax audit, and analyze the significances and role of tax audit in increasing tax revenue and in strengthening tax administration capacity. The results of the study indicated that the highest ratio of tax to GDP in Ethiopia was 13percent, which is registered in 2003/04. Most of the country's revenue is from non-tax sources such as grants. Revenue derived from taxes is dominated by indirect taxes. The study stated that personal income tax does not need critical assessment other than checking whether the amount withholds by the employer is forwarded to the respective tax authority. Whereas, business profit tax needs much effort to levy and collect due to the high-risk of understatement and evasion since most taxpayers use all mechanisms that could understate their tax liability. So far, there is no field audit although the problem of tax evasion bothers revenue agencies at different levels. Moreover, Getaneh (2011) focused on key problems in tax audit operation regarding the appropriateness of audit type used, audit rate, aptness of audit case selection methods, audit examination techniques used, and the experience and capability of audit staff resources at Federal Government level. The result of the study indicates that the tax audit program remains undeveloped with a slight range of tax audit activities performed targeting aptly specific risks. Further, low audit coverage, absence of compliance risk-based audit case selection strategy, scarcity of audit resources, and absence of proficient and experienced tax auditors are revealed as major problems in the study. Furthermore, the focus of the study conducted by Netsanet (2014) was on the Revenue Authority of Hawassa City Administration to examine whether the practice is in conformity with the standards. The study utilized interview and questionnaires to collect data required for the study. However, it has been difficult for the researcher to collect secondary data due to bad documentation of the authority and reluctance of its employees to cooperate with the researcher. The results of the study indicate that Revenue Authority of Hawassa City Administration extensively uses comprehensive types of audits. Due to this the audit coverage of the revenue authority was too low, cases were selected based on associated risk but not used the standard risk identification criteria. The Authority does not perform the audit work in a predetermined time. The study concludes that the revenue authority had not performed tax audits according to acceptable Tax Audit standards. Besides, a study made by Atisbha (2016) focused on tax audit practice and its challenges at Ethiopian revenue and customs authority with specific reference to large Taxpayers' office. Its objectives were intended to assess the challenges in the application of tax audit in the large taxpayers; to explore how tax audit is exercised in the reduction of tax avoidance and evasion, and to examine the competency of tax auditors of Ethiopian revenue and customs authority. The principal finding of this study was that declared income increased significantly more in the rational audit strategy group than in the control group. The results of the study indicate strongly that information concerning the use of rational audit strategies is superior to information concerning random audits, and that audit information, in general, is superior to no information. The information concerning the rational audit strategy reduces tax fraud compared to no information. According to this study, tax audits have an indirect deterred effect by which rational taxpayers adapt their behavior to the expected degree of auditing if they are made aware that they may be audited. The study further identified that tax audit practices in the authority had problems in the application of information technology /SIGTAS/ to its maximum capacities, incompetent auditors to tackle tax evasion and avoidance, weak taxpayers' education program which cannot improve the compliance level of taxpayers. Mebratu (2016) conducted a study to examine the impact of tax audit on tax compliance in Ethiopia, at federal level by using secondary macro data. To analyze the data the partial coefficient regression statistical analysis method was employed. The Pearson correlation and bivariate regression result of the study shows, there is a strong association between probability of audit detection and the level of tax compliance. Furthermore, the regression result of the study reveals that there is a strong association between the number of audited files and the level of tax compliance. Pearson Correlation and partial regression coefficient result of the study shows that there is a strong association between the probability of audit detection and the number of audited files with the level of tax compliance. The study concludes that since the contribution of tax audit on improving tax payer's compliance is significant among other measures, revenue authorities of the country and other concerned parties should give more emphasis on the role of tax audit by fulfilling the required staff and qualifications to improve tax payer's compliance and thereby increasing countries revenue through tax. 
Conceptual Framework

Figure 2.1: Conceptual framework of the study

Independent Variable Tax Audit

\section{Dependent Variable}

- Revenue protection system

- Tax automation

- Regulation

- The adequacy of tax audit resources

- proficiency and competency

- Amount of tax before audit

- Amount of tax after audit

- Tax evasion

- Compliance cost

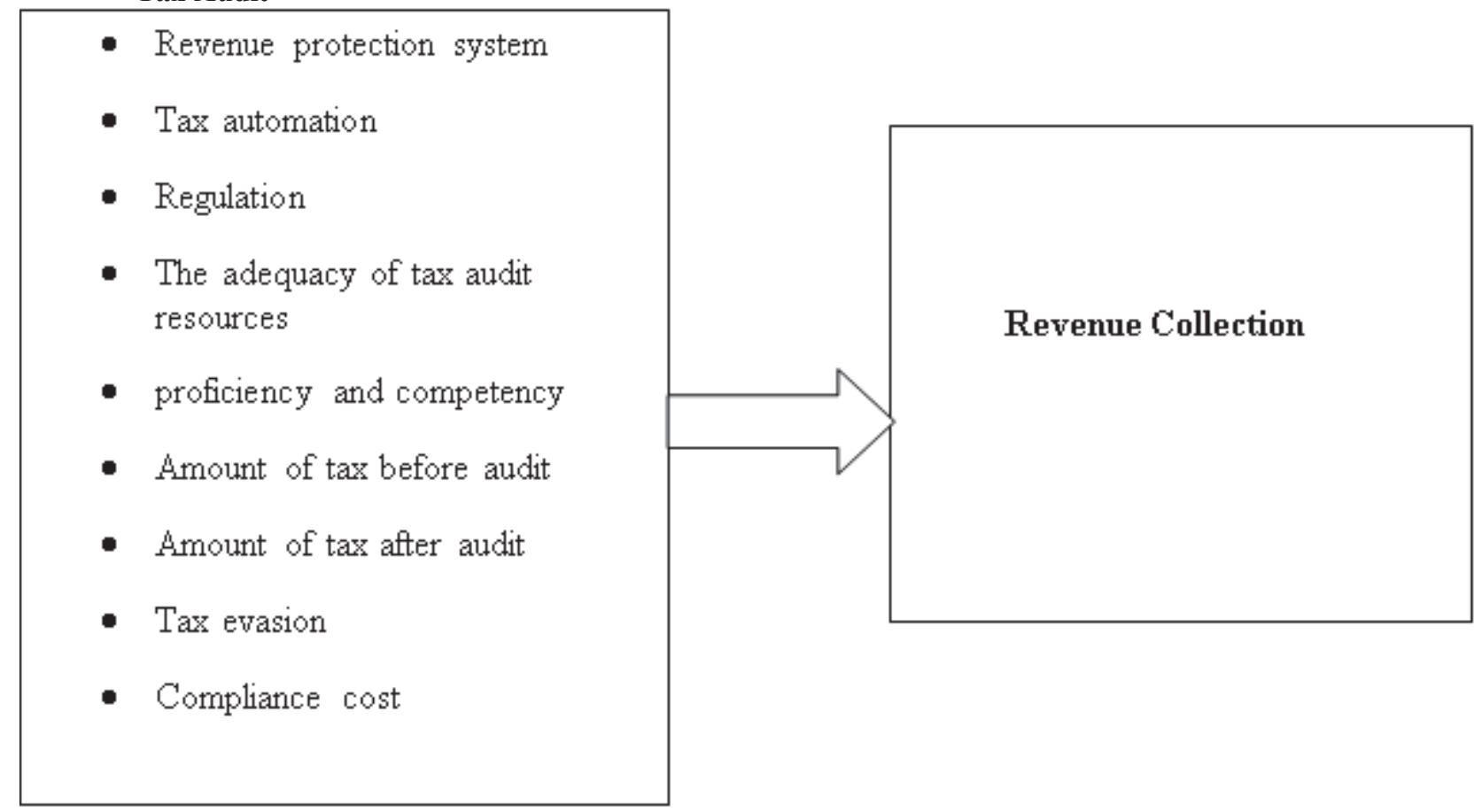

\section{Source: compiled by a researcher from past empirical studies}

\section{Research methodology}

To examine the effect of tax audit on revenue collection performance, the study used explanatory research design and mixed research approach.

\section{Target Population, sampling technique and sample size.}

The target population of the study was all tax auditors found in ERCA large taxpayers' offices. And they are 502 employees in number. The sampling technique used in this study was a purposive sampling technique; purposive sampling used to select the tax auditors from the total population of the study in order to represent that population. With regard to sample size, the study was delimited to a single department which is a tax audit office in ERCA LTO and the number of auditors in this branch is 98 and the study was conduct to all auditors. The reason for selecting is that they are a close attachment with tax audit functions and deep knowledge in the area of the study.

\section{Model equation of the study}

The following econometric model with its functional forms is given for this study.

$$
\begin{gathered}
L R C t=\beta 0+\beta 1 L B A t+\beta 2 L A A t+\beta 3 T R t+\beta 4 A C t+\beta 5 C A t+\beta 6 R P t \\
+\beta 7 T A t+\beta 8 T E t+\beta 9 T C t+c \ldots \ldots \ldots \ldots \ldots \ldots(1)
\end{gathered}
$$

Whereas; $\beta_{0}$ is the intercept and $\beta_{i}(\mathrm{i}=1,2,3,4,5,6,7,8,9)$ represents the coefficient for each of the independent variables.

$\mathrm{RC}=$ Revenue collection (measured as amount of revenue collected from tax payers under each month and natural logarithm is used).

$\mathrm{TR}=$ Tax audit resource

$\mathrm{CA}=$ capacity of the auditors

$\mathrm{AC}=$ audit case selection

$\mathrm{RP}=$ revenue protection system

$\mathrm{TA}=$ tax automation

$\mathrm{BA}=\log$ of income before audit (measured by the amount of income reported before tax by tax payers under each month and natural logarithm is used for this variable).

$\mathrm{AA}=\log$ of income after audit ( measured by the amount of income reported after tax by tax payers under each month and natural logarithm is used for this variable). 
$\mathrm{TE}=$ Tax evasion

$\mathrm{TC}=$ Tax compliance

$\mathrm{C}=$ is the constant term of the regression.

\section{Data Analysis and Interpretation}

In order to achieve the objective of the study; the researcher was used purposive sampling; to select a sample of respondents from the total population, So the data collected through a questionnaire distributed to respondents were analyzed and discussed. At the same time information obtained from secondary sources such as reports and related forms, action has been analyzed by using different tools. The researcher has distributed 98 questionnaires to respondents but only 84 questionnaires were returned and the rest of respondents did not return the questionnaire. As it can be discussed in the following subsections of the chapter; the study was targeted tax auditors as a population of the study. The questionnaire was prepared and distributed to the respondents; each variable was represented by proxy questions; the independent variable selected for the study was tax audit resources, audit case selection methods, the capacity of tax auditors, Revenue protection system, tax Automation, tax compliance, tax evasion .amount before audit and amount after audit. The data collected was analyzed through SPSS version 20.

Table 4.1: Summary of Descriptive statistics

\begin{tabular}{|l|l|l|l|l|l|}
\hline & $\mathrm{N}$ & Minimum & Maximum & Mean & Std. Deviation \\
\hline RC & 84 & 10.62 & 11.11 & 10.8698 & .12178 \\
BA & 84 & 9.13 & 10.83 & 10.2493 & .64991 \\
AA & 84 & 6.31 & 9.26 & 8.0320 & .72462 \\
TR & 84 & 2.60 & 4.40 & 3.6548 & .45028 \\
AC & 84 & 2.60 & 4.20 & 3.3762 & .35317 \\
CA & 84 & 3.00 & 4.60 & 3.7762 & .41117 \\
RP & 84 & 3.00 & 4.20 & 3.6000 & .40479 \\
TA & 84 & 3.20 & 4.60 & 3.7690 & .28706 \\
TE & 84 & 2.00 & 5.00 & 4.2381 & .66981 \\
TC & 84 & 2.00 & 5.00 & 4.1190 & 1.02269 \\
Valid N (listwise) & 84 & & & & \\
\hline
\end{tabular}

\section{Source: SPSS 20 output}

Note: According to Best (1977), standard deviation of the score from 1-1.80 is lowest, from 1.81- 2.61 is lower, from 2.62-3.41 is average/moderate, from 3.42-4.21 is good/high, and 4.22-5 is considered very good; Besides, the decision rules used in the analysis was average mean less than 3 was considered as low, average mean equal to 3 was considered as medium and average mean greater than 3 was considered as high (Best and khan1995).

The mean distribution of the dependent variable (RC) of the study is 10.8698 which are greater than 3 and standard deviation statistics for RC is 0.12178 , which is less than 1 .it shows the revenue collection performance in LTO is greater than its moderate level.

The mean distribution of amount before audit is 10.25 which are still greater than 3 and the standard deviation of 0.65 which is less than 1 which indicates that the amount of tax provided by taxpayers to tax authority before making any audit is greater than its moderate level. Which implies that; the tax payers report their total earning during the year to tax authority greater than the average amount the tax authority expect from them. On the other hand; the average mean value of variable income after tax audit is 8 with standard deviation value of 0.725 .

Tax audit resource abbreviated as TR, is proxied by number of audit staffs, resource materials, qualification and experience of the auditors, capability of auditors, and the commitment of individual auditors in performing audit activities. The data collected with regard to tax audit resources reveals that the mean distribution of 3.65 which are greater than 3 and the standard deviation of 0.45 which is less than 1 ; even though the standard deviation for variable is less than moderate level, the mean value of the variable shows that in view of the respondents there is high tax audit resource in large tax payer's office.

Audit case selection which is abbreviated as AC, is determined by responsibility of audit team, intelligence input support for audit program, frequency of auditing, availability of resource, and potential of tax payers. The mean value of audit case selection was 3.38, which is greater than 3 and this implies that respondents attitude on audit tax selection in large tax payers audit is greater than its moderate level. The variation of audit case selection measured by standard deviation was 0.35 which is less 1 of its moderate score. The other independent variable is capacity of auditors abbreviated as CA and proxied by skill of officers, ability to understand tax audit manual, training of auditors, and capacity of auditors in analyzing the audit standards. The data collected from the respondents with regard to the capacity of the auditors shows the mean value of 3.77 , which implies that the auditors at large tax payers, has a capacity to perform the audit programs. The variation of each observation from its mean value for this variable is 0.411 .

The variable revenue protection system is considered as an important variable in deciding the government 
revenue collection performance. The proxy used to measure this variable was confidentiality of tax audit, the legal frame work of the country, and strengthens of audit manual. The data collected with is variable shows the mean value of 3.6 and standard deviation of 0.40 . This implies that, in a view of the respondents' response the revenue protection system in large tax payers office is above the moderate level required by the government. The last variable of the study is tax automation abbreviated as TA and measured by application of tax automation, and educational level of the existing auditors to with tax automation. The data collected with this variable shows the mean value of 3.76 and standard deviation of 0.28 . The result of the data implies that the tax automation system at large tax prayers office is greater the moderate level required by tax authorities. The variable tax evasion and tax compliance have average mean value 4.24 and 4.11 respectively and standard deviation value of 0.67 and 1.022 respectively.

\section{Multiple regression analysis}

The study employed multiple regression models in the form of ordinary least square (OLS) and used a crosssectional data from auditors in large tax payer's office. The researcher undertook the diagnostic tests for the assumption of classical linear regression model (CLRM) before directly going to the multiple linear regression models. And the result of all tests shows that the model is viable.

\section{Multiple regression output and its discussion}

In this study, multiple regression analysis was carried out to get the predictive value of the variables considered. This was basically made to determine the linear combination of the constructs. The dependent variable of the study is revenue collection performance (RC) and independent variables are amount before audit (BA), amount after audit (AA), audit tax resources (TR), audit case selection (AC), auditors' competence (CA), revenue protection system (RP), tax automation (TA), tax evasion (TE) and tax compliance (TC).

Table 4.2: Result of Model summary

$$
\begin{gathered}
\text { LRCt }=\beta 0+\beta 1 L B A t+\beta 2 L A A t+\beta 3 T R t+\beta 4 A C t+\beta 5 C A t \\
+\beta 6 R P t \quad \beta 7 T R t+\beta 8 T E t+\beta 9 T C t+c
\end{gathered}
$$

Model Summary

\begin{tabular}{|l|l|l|l|l|l|}
\hline Model & R & R Square & Adjusted R Square & Std. Error of the Estimate & Durbin-Watson \\
\hline 1 & $.870^{\mathrm{a}}$ & .757 & .728 & .06355 & 1.847 \\
\hline
\end{tabular}

a. Predictors: (Constant), TC, AC, AA, RP, CA, TA, TE, TR, BA

b. Dependent Variable: RC

Table 4.3: Result of Anova table

ANOVA $^{\mathrm{a}}$

\begin{tabular}{|ll|l|l|l|l|l|}
\hline Model & & Sum of Squares & $\mathrm{df}$ & Mean Square & F & Sig. \\
\hline \multirow{4}{*}{1} & Regression & .932 & 9 & .104 & 25.641 & $.000^{\mathrm{b}}$ \\
& Residual & .299 & 74 & .004 & & \\
& Total & 1.231 & 83 & & & \\
\hline
\end{tabular}

a. Dependent Variable: RC

b. Predictors: (Constant), TC, AC, AA, RP, CA, TA, TE, TR, BA

The regression model output was presented in below table 4.7 and it shows the coefficients, standard errors, t-values, and p-values for explanatory variables. The overall summary of the model is presented in the above table 4.5 which implies the R-squared, adjusted R-squared and standard error of the estimates. The ANOVA result table shows F-statistics and probability (F-statistics) for the regression. The R-squared and Adjusted R-squared statistic of the model were $75.7 \%$ and $72.8 \%$ respectively.

The explanatory power of independent variables such as amount before audit, amount after audit, audit tax resources, capacity of the auditors, audit case selection, protection of revenue and tax automation, tax evasion and tax compliance on the change in dependent variable (revenue collection performance) was explained $75.7 \%$. The result of Adjusted R-squared shows that change on dependent variable (RC) was explained was explained $72.8 \%$ by the independent variables employed in the study. Therefore, $24.3 \%$ of change on dependent variable (RC) was explained by other factors which are not included in the model. The null hypothesis of F-statistic (the overall test of significance) which says the Adjusted R-squared is equal to zero was rejected at 1\% significance level. F-value of 0.0000 shows strong statistical significance which enhanced the reliability and validity of the model. 
Table 4.4: Result of coefficients Coefficients ${ }^{\mathrm{a}}$

\begin{tabular}{|c|c|c|c|c|c|c|}
\hline \multirow{2}{*}{\multicolumn{2}{|c|}{ Model }} & \multicolumn{2}{|c|}{ Unstandardized Coefficients } & Standardized & \multirow[t]{2}{*}{$\mathrm{t}$} & \multirow[t]{2}{*}{ Sig. } \\
\hline & & B & Std. Error & Beta & & \\
\hline \multirow{10}{*}{1} & (Constant) & 10.848 & .298 & & 36.387 & .000 \\
\hline & BA & -.066 & .018 & -.354 & -3.767 & .000 \\
\hline & AA & .006 & .010 & .034 & .593 & .555 \\
\hline & TR & -.093 & .021 & -.345 & -4.407 & .000 \\
\hline & $\mathrm{AC}$ & .051 & .029 & .149 & 1.787 & .078 \\
\hline & CA & .053 & .026 & .178 & 1.997 & .050 \\
\hline & $\mathrm{RP}$ & .120 & .020 & .399 & 5.925 & .000 \\
\hline & TA & .072 & .029 & .169 & 2.452 & .017 \\
\hline & $\mathrm{TE}$ & -.054 & .013 & -.298 & -4.025 & .000 \\
\hline & $\mathrm{TC}$ & .037 & .008 & .307 & 4.558 & .000 \\
\hline
\end{tabular}

a. Dependent Variable: RC

The model equation is

$$
\begin{gathered}
R C=10.848-0.066(B A)+0.006(A A)-0.093(T R)+0.051(A C) \\
+0.053(C A)+0.120(R P)+0.072(T A)-0.054(T E) \\
+0.037(T C)
\end{gathered}
$$

The result of regression out reveals that before audit amount of the tax payer income has a negative relationship with revenue collection performance with a beta coefficient value of -0.066 and statically significant at $1 \%$ significance level. The result of the regression output implies that 1 unit increases the income of the tax payers before audit causes the revenue collection performance to decrease by 6.6 percent and statistically significant at 1\% significance level. The negative relationship between two variables can be expected since Ethiopia applies progressive tax system. For that, if the companies earning ability before making any audit tax increases it will increase the level of revenue collection for that purpose the tax payers are encouraged to understate the total earning of the companies by overstating artificial expenses. . Additionally, taxpayers those registered at ERCA-LTO are classified as large taxpayers in the country, so increasing their level of income before tax will deliberately increases the tax liability which causes revenue collection to increase at ERCA-LTO. On the other hand, the relationship between revenue collection performance and after audit amount of tax found positively correlated. The result of regression analysis implies that 1 units increase the amount of tax after audit cause's revenue collection performance to increase 0.6 percent and not statically significant even at 10 percent significance level. The variable audit tax resources have a negative relationship with revenue collection performance at ERCALTO. The result of regression out implies that 1 unit increase in tax audit resources causes revenue collection performance to decrease by $9.3 \%$ and statically significant at 1 percent significance level. The implication of negative relationship between the variables is an indication of that; ERCA-LTO does not fulfill the questions provided under audit tax resources. The questions were included are; whether there is enough audit staff to perform audit program in the office, enough resource materials, experienced and qualified audit staffs, and necessary trainings to improve the capability of the auditors. So, the result of the data collected from respondents implies that ERCA-LTO has no enough audit tax resources to perform the audit activities. An audit case selection at ERCA-LTO found positively and statically affects revenue collection performance. The result of regression out reveals that 1 unit increase in audit case selection causes revenue collection performance to increase by 5.1 percent and statically significant at 10 percent significance level. This implies that; the more the office focus on audit case selection the more the revenue will collect. So, it is possible to understand that; ERCA-LTO is performing its audit case selection in line with the questions provided at under the variable of the study. The auditors' capacity found positively correlated with revenue collection performance of the office. The result of regression out reveals that 1 unit increase in auditors' capability causes revenue collection performance to increase by 5.3 percent and statically significant at 10 percent significant level. Since auditors capacity was measured by auditors' skill, number of trainings given, and ability to understand the audit manual; the more auditors capacity the more revenue collection performance. The revenue protection system, tax automation and tax compliance are found positively affects revenue collection performance and statistically significant. The result of regression output reveals that 1 units increase in revenue protection system causes the revenue collection performance to increase by 12 percent and statistically significant at 1 percent significance level. Additionally, 1 units increase in tax automation leads the revenue collection performance to increase by 7.2 percent and statically significant at 1 percent significance level. The implication behind positive relationship between revenue collection performance and tax automation is 
that; increase the level of tax automation( updated software's for revenue collection, different type of application for revenue collection) speed up overall service quality of the office and reduce the compliance cost. Furthermore, the regression out reveals that 1 unit increase in tax compliance causes revenue collection performance by 3.7 percent and statically significant at 1 percent significance level. The implication of positive relation between variables implies that the more awareness by the office to tax payers on tax compliance increases overall revenue collection of the ERCA-LTO.

The last variable used in this study is tax evasion. The regression output reveals that the tax evasion affects revenue collection performance negatively and significantly. The result of regression output indicates that 1 units increase in tax evasion will cause revenue collection to decrease by 5.4 percent and statically significant at 1 percent significance level. The implication of negative relationship between variables implies that; the more tax evasion occurred by tax payers it deliberately decreases the revenue collection at ERCA-LTO.

\section{Conclusion}

This study is conducted to examine the effect of tax audit on revenue collection; evidence from ERCA-LTO. In doing so, some variables measured as proxy to the tax audit was included. The study was conducted through primary and secondary data conducted from ERCA-LTO and the secondary data collected was covers 7 years monthly observation (2005-2011). The study adopted explanatory research design and mixed research approach. In order to estimate the extent of the effects of each variable, several tests were needed to be done. Firstly, a multicollinearity test was checked through correlation matrix; in order to see, if there was any issue between variables. Then, other tests (such as the auto correlation, normality, and heteroscedasticity tests), were confirmed that a model is feasible. To analyze the descriptive statistics, the researcher used the mean, maximum, minimum and standard deviation of all variables. Further, the researcher discussed regression analysis to determine the effect of independent variables on the dependent variable. Therefore, in line with the specific objective of the study the researcher reached at the following conclusion. The finding of the study reveals that revenue collection is positively correlated with the variables included in the study except one of the variable. Subsequently the following sections discuss the finding of each variable.

The result of regression analysis indicates that; the variable tax audit resource (which is measured by number of staffs, availability of audit materials, experience and qualification of the auditors, and commitment of the auditors) has a negative effect on revenue collection and statistically significant at 1 percent significance level. On the other hand; auditors' capacity (which is measured by skill of auditors, capacity of the auditors, frequency of audit training and quality of audit manuals) has a positive effect on revenue collection performance and statistically significant at 10 percent significance level. The variable revenue protection system (which is measured by confidentiality of tax audit and legal frame work of audit activities) has a positive and significant effect on revenue collection performance. The result of regression analysis reveals that revenue protection system has positive effect and statistically significant at 1 percent significance level. Additionally, audit case selection (which is measured by level of responsibility of team leaders, and frequency of audit activities) has positive effect on revenue collection and statically significant at 10 percent significance level. The income of tax payers before audit and tax evasion has a negative effect on revenue collection respectively and statically significant at 1 percent significance level. While on the other hand; income after audit of tax payers has a positive and insignificant effect on revenue collection at ERCA-LTO. Furthermore, tax compliance was found positively affects revenue collection performance and statically significant at 1 percent significant level. From the above finding of the study the researcher can concluded that; tax audit found the significant variable which affect revenue collection performance at ERCA-LTO.

\section{References}

Adedrian, S., \& Alade, S. (2013). The impact of tax audit and investigation on revenue generation in Nigeria. European journal of business and management.

Al Zakari, I. A. (1995). Corporate tax compliance: a case study of Saudi Arabia University of New Mexico. A case study of Saudi Arabia University of New Mexico, Ph.d.

Apostolou, B, Pasewark, W.R, Strawser, J. R. (1993). The Effect of Senior Internal Auditor Behaviours on Staff Performance and Satisfactions. Accounting and Business Research,23(29), 110-123.

Arindam, D.G. (1999). Performance Indication for Tax Structure and administration. The World Bank.

Azubike, J. B. (1999). Challenges of Tax Authorities, Tax Payers in Management of Tax Reform Process, the Nigerian Accountant, Vol.42 (2): 36-42. Vol.2, No. 12, 2016.

Bahl, R. A. (2008). Tax Policy in Developing Countries: Looking Back - and Forward. National Tax Journal, pp. 279-301, pp. 296.

Bello, T. (2001). The role of taxation in Nigeria Economy (a case of Kano State Board of Internal Revenue). MBA unpublished project, Department of accounting BUk Kano, Nigeria.

Biber, E. (2010). Revenue administration: Taxpayer Audit Development of Effective Plans Technical Notes and 
Manuals, IMF, Fisical Affairs Department, available at, $<$ http://www.imf.org/external/ft/tnm/2010/tnm1003.pdf $>$, accessed on July 2018.

Brautigam, D. (2008). Introduction of Taxation and State-Buildingin Developing Countries.

Brown, R. E. (2003). "IRS's comprehensive Approach to compliance Measurement" Internal Revenue Service.

Collins, J. H. (1991). The taxpayer's Labor and Reporting Decision: The Effect of Audit Scheme, The accounting Review, Vol.66 No. 3, pp.559-576, American Accounting Association, available at $<$ http://www.jstor.org/stable/247809>, accessed on August 2018.

Creswell, J. W. (2009). Research design: Qualitative, Quantitative, and Mixed Methods Approaches, 3rd edn. California, USA. Sage Publications.

Damme, L. T. (2008).Taxation Policy in Developing Countries: available at $<$ http://visar.csustan.edu/aaba/LaurenDamme.pdf $>$, accessed on September 2018 Ebrill (2010) the Modern VAT, IMF, Washington DC.

Ebrill, L., Keen, M., Bodin, J.and Summers. (2011). 'The Modern VAT', Washington D.C:

International Monetary Fund, V.2001. EC. (2006). 'Compliance Risk Management Gide for tax

Erard, B. (1994). "Honesty and Evasion in the Compliance Game". The RAND Journal of

Economics 25(1): 1-19 Forums on tax payers Administration (2004). Managing and improving Tax Compliance. New York, USA.

ERCA. (2010). Tax and post clearance audit policy and strategy retrieved on December 13, 2012 from http://www.erca.gov.et/Approved\%20Policy.pdf.

Eugene, N. (2011). Improving Revenue Collection through Tax Audit Practice: The Case of Ghana Revenue Authority.

FDRE. (2008). Ethiopian Revenue and Customs Authority Establishment Proclamation No 587/2008, Federal Negarit Gazeta, 14th year No 44, Addis Ababa 14th July 2008, Ethiopia.

Field. (2009). Discovering Statistics Using SPSS. Sage: London.

Getaneh, M. (2011). Tax audit practice in Ethiopia: the case of the federal government, Addis Ababa University, Ethiopia.

Gilbert, M. I. (2001). The Impact of IT on accountability and audit, in tax administration in the $21^{\text {st }}$ century IS. Walpole, \& C. Evans,. Editors Prospect Media, Sydney.

Grandcolas, C. (2005). "Management of the VAT: Improving the level of Compliance using Performance Indicators, Lessons for the Pacific Islands Countries", 15th Tax Conference, October2005, Tokyo,Japan,avialable http:/www.adb.org/documents/Tax Conference/paper grandcolas.py.

Griffeth, R. \&. (2001). Retaining valued emplyees. USA. Gupta, M. a. (n.d.). "Audit Sellection Strategy for Improving Tax Compliance: Appilication of Data Mining Techiniques", Avialableat, <http://www.csisgegov.org/1/39_354.pdf>, accessed June 2018.

Handelsman, J.(2009).Understanding and Remedying Employee Turnove. URL :http://www.toolkit.com/newstandard devation (SD)etail.aspx?nid=138turnover .

Harrison, G. A. (2005). VAT refunds: Areview of country experiance, IMF Working Paper

No.05/218, IMF, WashingtonDc, Avvialable<http://www.imf.org/external/pubs/ft/wp/2005/wp05218.pdf>, accesses on June 2018.

Hellenrstein. (2005). " The VAT Experiances and Issues", A Paper for the International Tax

Dialogue Conference onthe VAT, 2005, Rome, Avialable at, http://www.itdweb.org. Is

Collaboration the key? Australian Tax Form, Accesses on July 2018. 